Linguistik Terapan 15 (1) (2018): 69-78

Jurnal Linguistik Terapan Pascasarjana

Available online http://jurnal.unimed.ac.id/2018/index.php/JLT-

Unimed

\title{
TRANSLATION SHIFTS IN TRANSLATING DIDONG TEXTS FROM GAYONESE INTO BAHASA INDONESIA
}

\author{
Wike Yurida \\ Anni Holila Pulungan \\ Rahmad Husein
}

Diterima Januari 2018; Disetujui Pebruari 2018; Dipublikasikan April 2018

\section{ABSTRACT}

The research deals with the occurrence of shift in Translating Didong texts from Gayonese into Bahasa Indonesia. The objectives of the study were: (1) to find out the types of shifts in Translating Didong texts from Gayonese into Bahasa Indonesia, (2) to describe how the shifts occur in Translating Didong texts from Gayonese into Bahasa Indonesia, (3) to analyze the reasons why translation shifts occur Translating Didong texts from Gayonese into Bahasa Indonesia. The research was conducted by using descriptive qualitative design. The data of this study were clauses which translated from Gayonese into Indonesian. The data were collected through documentary technique. The technique of data analysis was interactive model. This research was found that there were five types of translation shift. The type of structure shift was the dominant type. The findings of this study revealed that: (1) The category shifts in Translating Didong texts from Gayonese into Bahasa Indonesia are 1) structure shift, 2) class shift, 3) unit shift, 4) reduplication word shift, and 5) double types of shift. (2) There were some ways of translation shift used in Translating Didong texts from Gayonese into Bahasa Indonesia, namely grammatical change occurred, change in different word class and change in ranks. (3) There were four reasons of using translation shifts are (1) Different language systems, (2) Grammatical structures of SL do not exist in TL, (3) Literal translation is grammatically possible but may not accord with natural usage in the TL (naturalness between SL and TL) and (4) replacing virtual gap by grammatical structure.

Keywords: translation, translation shifts, Didong texts.

How to Cite: Yurida, Wike (2018). Translation Shifts in Translating Didong Texts From Gayonese into Bahasa Indonesia. Jurnal Linguistik Terapan Pascasarjana Unimed, 15 (1): 69-78 ISSN 2407-7410 


\section{INTRODUCTION}

Translation is one of field in applied Linguistic that concerned about transferring the message from the source language into the target language. In conducting the translation, a translator has to know the rule of translation. Therefore in translating a language, a translator must comprehend the source language and the target language. There are some studies of translation, such as the strategies of translation, the technique of translation, equivalences and shifts. Every language has its own language system. There are many languages in this world even in a country. Therefore the translation studies are useful in linguistic.

Indonesia is a multicultural country. Therefore there are many local languages in Indonesia even in a province has some local languages. One of province in Indonesia which has some languages is Aceh. Kelana (2009) states Aceh province consist of nine local languages, they are; Aceh, Gayo, Alas, Tamiang, Jamee, Kluet, Singkil, Haloban and Simeulue. In this case the role of translation is very important, because there still some people in deep district cannot speak Bahasa Indonesia. Therefore a translator of local language has an important role in communication. In addition, a translator of local language has a role to maintain the local language.

Bahtiar (2015) states if Gayonese language is not used as a mother tongue on Gayonese people, it will be lost in the next generation of Gayonese. One of the realizations is that the young generation of Gayonese miscomprehend in Didong texts. Didong is one kind of traditions in Gayonese. It consists of the speech with rhythm of one or two person in a group and also equipped by dance of hand is like rhythmic clapping hands from the other members in a group of Didong. Usually Didong conduct in wedding ceremony, seminar, and regional events. Ibrahim and Pinan (2005) stated that Didong comes from the art of dance and literature, equipped with several types of traditional instruments. In addition, Masri (2015) conducted the interviewed with the expert of Didong Onot Kemara states that when He asked a Gayonese student in one of university in Aceh about Didong and the student do not know about Didong. Kemara dissatisfied with this case. Didong is one of the identities of Gayonese, therefore Didong needs to be maintained. Based on the description above, the researcher wants to conduct the research about Didong.

Translation shifts is a branch of translation study. Translation shifts are the study which is concern with the shifts of the system of the language from the source language into the target language. Catford (1965: 141) states that translation shifts is the departure from the formal correspondence in the process of going from the source language into target language. The word "formal" in" formal correspondence "comes from the word" form "(form), so it means "linguistic form"; therefore it can also be translated into similarities linguistic form (Hariyanto, 2009). Based on explanation above, Catford states the translation shifts realize if there is no formal correspondence (similarities linguistic) in the source language and target language. In this case, the researcher found 
the translation shifts realization is not always caused by formal correspondence in the source language and the target language. Based on the observation of Didong texts in a book by Ibrahim and Pinan, the researcher found the preliminary data as the following:

ST: kati enti musuet kepile gadung (so that the sweet potato and cassava do not take)

TT: agar aib tidak tercuat (for shame is not coming up)

The translation above shows that there are shifts in meaning and structure. In meaning shifts, the words kepile gadung was translated into aib. Actually, the words kepile and gadung have meaning ubi jalar and ubi kayu in Bahasa Indonesia. The structure shifts in the translation above is enti musuet (modifier) kepile gadung (head) in the source texts, but in target texts become aib (head) tidak tercuat (modifier).

Another data of translation shifts;

ST: kati mutuah ko tudung payung (for happiness be with you)

TT: supaya kamu berbahagia (for you to be happy)

Based on the translation above, there is meaning shifts. The words tudung payung in source texts was not translated in the target language. It just translated the words kati mutuah ko into supaya kamu berbahagia. Then also there is structure shifts, mutuah ko (modifier+head) into kamu berbahagia (head+modifier).

ST: oya jaluni radio puntung (that is offense of 'radio puntung' (a person who give the issues/gossip))

TT: itu adalah berita mengadu (that is a gossip)

On the translation above, there is shift in meaning. In source texts there is no word to be translated into adalah in target texts. The words jaluni radio puntung translated into berita mengadu. Actually the word jaluni means mengadu in Bahasa Indonesia, meanwhile radio puntung means radio putus.

\section{ST: juru benar enti sawah mubah (the truth should not be changed) \\ TT: jangan berubah dari kebenaran (not change from the truth)}

Based on the translation above the word benar in source language was translated into kebenaran in target language. The adjective benar in source language is changed into adjective in target language kebenaran. Then, it's called as class shifts, the changing of adjective in source language into noun in target language. A source language item was translated in a target language item which belongs to a different grammatical class. It occurs where literal translation is grammatically possible but may not accord with natural usage in the TL so it is the matter of naturalness between SL and TL.

There were some studies about the translation shifts, (Karina and Nurfitriani, 2017, Herman, 2017, Salemi and Lotfi, 2017, Khanmohammad and Daneshfar, 2015, Herman, 2014, Maasoum, 
2013), focusing on analysis the category of shifts based on Catford's theory; unit shifts, class shifts, structure shifts and intra-system shifts. Another study Widarwati (2015) focused on rank-shifts in translating the sentence. Rank-shifts in the translation of compound complex sentences are: simple sentence, compound sentence, complex sentence and compound complex sentence. Other, Abdullahi and Singh (2017) studied the structure shifts, meanwhile Miranti (2017) not only focused on category shifts but also in level shifts. There are two kinds of level shifts in this study: clause-to-word shifts and clause-to-phrase shifts. Based on some studies above, there are level shifts, category shifts and rank shifts in translation shifts. Conducting translation research of Didong texts is a new research in translation shifts. Therefore the researchers try to conduct the research in order to maintain the local language of Gayonese.

Based on the preliminary data above, the researcher wants to conduct the research about translation shifts in translating Didong from Gayonese into Bahasa Indonesia. This study was focused to find out the types, the process and the reason of translation shifts in translating Didong texts from Gayonese into Bahasa Indonesia. By conducting the research, the researcher hopes the finding of translation shifts in this phenomenon will add the knowledge about translation shifts and also through conducting the research in Didong texts will inspire the Gayonese people to do the research about Gayonese language in order to maintain the local language.

\section{REVIEW OF RELATED LITERATURE}

Based on Oxford Advance Leaner's Dictionary (1985), "Shift is change position or place, substation of one thing to another". Catford (1965:141) gives the idea on shift, namely "The change of formal structure of the Source language into the Target language".

Catford (1965: 80) classified the translation shift into two major types of shift are identified: Level Shift and Category shift. Level shifts means a SL item at one linguistic level has a TL translation equivalent at a different level. This shift commonly occurs with shift from grammar to lexis and vice versa. However, category shift means change from the formal correspondence in translation. Furthermore, it is divided into structure shift, class shift, unit shift, and intra shift. (Catford, 1965)

1. Structure-shifts.

Languages exhibit a considerable amount of differences both in the realization of similar structures existing in these languages and in the type of structures existing in each language. It is worth mentioning here that the distinction between deep representation of linguistic relations and their surface realizations constitutes an important phase for the analysis of structural shifts. A structure shift involves a change in grammatical structure between ST and target text TT. It also involves a grammatical change between the structure MH (modifier + Head) into HM (Head + Modifier). 
2. Class-shifts, that grouping members of a given unit which is defined by operation in the structure of the unit next above. Class shift occurs when the translation equivalence of an SL item is a member of a different class from the original item. It is a change in word class. Catford defines class shifts following Halliday's definition "that grouping of members of a given unit which is defined by operation in the structure of the unit next above. Structure shifts entail class shifts. This is because of the "logical dependence of class on structure" (Catford, 1965:119).

3. Unit-shifts

A unit shift where a strict rank-for-rank correspondence between SL and TL sentences, clauses, groups, words and morphemes is not observed: e.g. the English definite article translated by a change in word order in Russian; (Catford, (1965: 80) Unit shifts occur when translation equivalent of a source text unit at one rank in is a unit at a different rank in the target language. It involves changes in rank, that is departures form formal correspondence in which the translation equivalent of unit at one rank in the source language (SL) is a unit at different rank in the target language (TL)

4. Intra-system shifts, which occur when SL and TL possess systems which approximately correspond formally as to their constitution, but when translation involves selection of a noncorresponding term in the TL system ${ }^{e}$. For instance, when the SL singular becomes a TL plural.

\section{RESEARCH METHOD}

This research was conducted by qualitative data analysis. The research was about descriptive qualitative research specifically in content analysis. The data of this research wereclauses in Didong text which consisting of translation shift in Gayonese intoBahasa Indonesia. The text of Didong was separated in clauses form on the table. The source of data in this study was text-book entitle Syari'at dan Adat Istiadat by Ibrahim and Pinan (2005). In this book there are thirty-one Didong texts in fifty pages of Didong texts in Gayonese and Bahasa Indonesia. The procedures of administrating the data as following: (1) Reading the Didong texts; (2) Identifying the subject matters; (3) Selecting the clauses consisting of translation shift; (4) Categorizing the data, interpreting and making the general findings.

\section{FINDINGS AND DISCUSSIONS}

\section{Findings}

The data were collected through the document which was from Didong texts. The texts consisted eight texts which told about culture in Gayonese. The data were the clauses by bold type in Didong texts. The data were collected by identifying and listing the clauses in Didong texts. In data collection there were 157 data clauses contained the category shifts in Didong texts. 
The step of selecting means the way to choose the most suitable data. In this research the researcher chose the best data selection based on the types of shifts used in translating Didong texts from Gayonese into Bahasa Indonesia, the process and the reason of shifts occurred in translating Didong texts from Gayonese into Bahasa Indonesia. There were 157 data consisted of structure shift, class shift, unit shift and double types of shift occurred in translating Didong texts from Gayonese into Bahasa Indonesia as shown in Table 4.1.

Table 4.1 Selecting data

\begin{tabular}{cccc}
\hline $\begin{array}{c}\text { No. } \\
\text { Data }\end{array}$ & Source Language & Target Language & $\begin{array}{c}\text { Category } \\
\text { Shifts }\end{array}$ \\
\hline & Enti sara kude gerel morowan & Jangan seekor dikatakan dua & Structure \\
\hline 3 & Gelah ati-ati iwan pendaptaran & Hati-hati mendaftarkannya & Class \\
\hline 40 & Sene ni kekanak sawah ku tetuwe & Sendau anak sampai orang tua & Unit \\
\hline
\end{tabular}

Based on the Table 4.1, the data were selecting by choosing the clause that containing the shift in translating Didong text from Gayonese (source language) into Bahasa Indonesia (target language).

The second step in data condensation was focusing. The researcher focused on the keywords in the clause which containing the translation shifts. In a data of each clause there was keyword as the indicator of translation shift. The word, phrase or clause in source language was shift in the target language, such as a word clause in source language became a phrase in the target language. The keywords were sign by bold typing. The example can be seen below:

Table 4.2 Focusing data

\begin{tabular}{lll}
\hline $\begin{array}{c}\text { No. } \\
\text { Data }\end{array}$ & \multicolumn{1}{c}{ Source Language } & Target Language \\
\hline 4 & $\begin{array}{l}\text { Enti sara kude gerel } \\
\text { morowan }\end{array}$ & Jangan seekor dikatakan dua \\
\hline 3 & $\begin{array}{l}\text { Gelah ati-ati iwan } \\
\text { pendaptaran }\end{array}$ & Hati-hati mendaftarkannya \\
\hline 40 & $\begin{array}{l}\text { Sene ni kekanak sawah } k u \\
\text { tetuwe }\end{array}$ & Sendau anak sampai orang tua \\
\hline
\end{tabular}

The data above were some of the whole data.

The third step was simplifying. The researcher simplified the data. It was to make easier in understanding. It can be shown in this Table 4.3 below.

Table 4.3 Simplifying Data

\begin{tabular}{|c|c|c|c|}
\hline No & $\begin{array}{l}\text { Category } \\
\text { Shifts }\end{array}$ & SL & TL \\
\hline 1 & Structure & $\begin{array}{l}\text { - Kude kemili nge gatin ku rebe } \\
\text { - Si munamat kekang turah ati- } \\
\text { ati }\end{array}$ & $\begin{array}{l}\text { - Kude kemili ke kebun selalu } \\
\text { - Hati-hati pemegang kekang } \\
\text { - Satu keliling cepat sedikit }\end{array}$ \\
\hline
\end{tabular}




\begin{tabular}{|c|c|c|c|}
\hline & & - Betul keras ike seger belit & \\
\hline 2 & Class & $\begin{array}{l}\text { - Wo kayu rubu ijomi ko pucuk } \\
\text { - Gelah ati-ati iwan pendaptaran }\end{array}$ & $\begin{array}{l}\text { - Wahai kayu berpucuk rimbun } \\
\text { - Hati-hati mendaftarkannya }\end{array}$ \\
\hline 3 & Unit & $\begin{array}{l}\text { - Sene ni kekanak sawah ku tetuwe } \\
\text { - Kaman enti payah mujajangkat } \\
\text { rege }\end{array}$ & $\begin{array}{l}\text { - Sendau anak sampai orang } \\
\text { tua } \\
\text { - Daripada capek membawa } \\
\text { raga }\end{array}$ \\
\hline
\end{tabular}

Double

types of

shift;

- Ulak ku umah gere beriro

- Tidak menghiraukan

- Structure

and class - Macam-macam dele perayaan

- Structure and unit

- Structure and unit

- Mu pitun belit nge muputerputer keluarga

- Perayaan beraneka ragam

- Berkeliling tujuh kali himpun

Based on Table 4.3, the data were analyzed in the form of table.

The following table was about the recapitulation of types of translation shifts in translating Didong text from Gayonese into Bahasa Indonesia.

Table 4.4 Abstracting Data

\begin{tabular}{|c|c|c|c|}
\hline No. & Category shifts & Data & Percentage (\%) \\
\hline 1 & Structure & 120 & 76.4 \\
\hline 2 & Unit & 16 & 10.2 \\
\hline 3 & Class & 2 & 1.3 \\
\hline 4 & Reduplication word & 8 & 5.1 \\
\hline 5 & $\begin{array}{l}\text { Double types of } \\
\text { Shifts }\end{array}$ & 11 & 7 \\
\hline & Total & 157 & 100 \\
\hline
\end{tabular}

From the data above, Table 4.3, it could be seen that the translation shifts applied in translating Didong texts from Gayonese into Bahasa Indonesia, and there were 3 of category shifts found, namely: structure shift, class shift and unit shift. In addition, there were some data in double types of category shifts

After analyzing the data, there were five types of translation shifts found in translating Didong texts from Gayonese into Bahasa Indonesia, namely: Structure Shift, Unit Shift, Class Shift, Reduplication word shift and Double types of shift. There were 157 data in this research, they were divided into structure shift was used 120 data, unit shift was used 16 data, class shift was used 2 data, reduplication word shift was used 8 data and Double types of shift was used 11 data. Reduplication word shifts and double types of shifts were the new findings on this research, meanwhile the other were the existing types of category shift based on Catford's theory. There was no intra system shift from Catford's theory found in this research, because there was no shift in numbering of meaning from the source language Gayonese into the target language Indonesian. 


\section{Discussions}

Based on the analysis of data above, there were some points as the important ones to be discussed in this study. It was very important to match whether the result of the study were contrastive to the theories.

There were five types of translation shifts in translating Didong texts from Gayonese into Bahasa Indonesia namely: structure shift, unit shift, class shift, reduplication word shift, and double types of shift. When the findings of this research were compared to another relevant research finding as in Salemi (2017), it was found that the structure shift was the most frequent type which was similar to the finding of this research. While in Widarwati (2015), Herman (2014) and Maasoum (2013) found that the dominant shift occurred was unit shift. The difference occurred because of the linguistics characteristics of the data from the source language to the target language on these researches were dominantly had different in the ranks of phraseor clause.The four categoryshifts from Catford's theory occurred in some researches including in Abdullahi (2017), Karina (2017),Miranti(2017).

Meanwhile this research there was no found the one of type's category shifts from Catford's theory namely Intra system-shift. It was because there was no data change or shift in numbering of the meaning from the source language into the target language. Intra system shift occurred in translating between English and Bahasa Indonesia, such as; English: there are some books on the table, Bahasa Indonesia: ada beberapa buku di atas meja. The word 'books' in plural form was shift into singular form 'buku'. In translating between Gayonese and Bahasa Indonesiaespecially on this research data from Didong textsthere was no shift in numbering of meaning. Therefore, this study contradicted the Catford's theory, especially of intra system shift.

In addition, there were two types of translation shifts in translating Didong texts from Gayonese into Bahasa Indonesiaas the new findings, namely: Reduplication word shift and Double types of shift. Reduplication word shift was a shift which occurred from a word in source language become reduplication word on the target language or the opposite, such as; Gayonese: Inget bibirmu kase mucecerah, Bahasa Indonesia: Ingat bibirmu pecah-pecah. A word 'mucecerah'from Gayonese was shift into a reduplication word 'pecah-pecah'.A double type of shift was a type which consists of two types of shift in one data, such as there were structure shift and unit shift in one data.These findings was have not found in the previous research, therefore these types were the new findings.

This study found that there were three waysof translation shifts in translating Didong texts from Gayonese into Bahasa Indonesianamely: Grammatical change, Change in ranks, and Change in word class.TheGrammatical change was referring to the realization of structure shift, such as the shift from the pattern of Modifier+Head in the source language into Head+Modifier in the target language. The second way was Change in ranks. It was referring to the realization of unit and reduplication word shift. There were some data changed from word in the source language into phrase in the target language, or the opposite. The third was Change in word class. It was referring to the realization of 
class shift, such as from noun in the source language into verb in the target language. This way was the less found on this research, because the data were not many found the shift in word class in translating Didongtexts from Gayonese into Bahasa Indonesia.

The reasons of translation shifts in translating Didong text from Gayonese into Bahasa Indonesia were divided into four, namely: Language system, Grammatical structure, Literal translation, and Replacing virtual gap.Based on Newmark (1988:85) which found that SL and TL have different language systems so the shifts occurred automatically and translators have no options but to undergo those shifts as in the translation of Gayoneseone word to Indonesian reduplication words and the position of adjectives. Another reason was because the grammatical structures of SL do not exist in TL. Further, shifts also occurred because the literal translation is grammatically possible but may not occur with the natural usage in the TL so it is the matter of naturalness between SL and TL, for example the change of word class from noun to verb. The last, shifts occurred because of replacing virtual lexical gap bychanging the form from of a word in the source language into more than one word in the target language, such as the change from word to phrase, phrase to clause in the translation.

\section{CONCLUSIONS}

Based on the research findings, some conclusions were drawn as the following:

1. The types of translation shifts used in translating Didong texts from Gayonese into Bahasa Indonesianamely: Structure shift, Unit shift, Class shift, Reduplication word shift and Double types of shift.There were two types of translation shift on this research as the new findings, namely: Reduplication word shift and Double types of shift. Meanwhile the intra system type was not found in this research, because there was no shift in numbering of meaning from this research data.

2. The ways of translation shifts used in translating Didong text from Gayonese into Bahasa Indonesia, namely: Grammatical change, Change in ranks, and Change in word class. The change of grammatical structure from Modifier+Head into Head+Modifier, active sentence into passive sentence. The change of ranks was like from word into phrase, a word into reduplication words. The change of word class, a noun can be translated into verb, and the verb can be translated into a noun.

3. The reasons behind the occurrence of shifts that used in translating Didong texts from Gayonese into Bahasa Indonesia were the different of language system, the different of grammatical structure, literal translation, and replacing virtual gap.

\section{REFERENCES}


Abdullahi and Singh. 2017. Structure Shift of Conjunctive Relations in Translation Animal Farm from English into Hausa. Petanika Journals Social Sciences and Humanities.

Bahtiar. 2015. Bahasa Gayo Terancam Punah. Retrieved from http://www.insetgalus.com/berita?id=Bahasa_Gayo_Terancam_Punah. Accessed on December, $12_{\text {nd }} 2017$.

Hatim, B. \& J. Munday 2004. Translation: An Advanced Resource Book. London/New York: Routledge

Ibrahim, M and Hakim Aman Pinan. 2005. Syari'at dan Adat Istiadat. Takengon: Yayasan Maqamam Mahmuda Takengon.

Khanmohammad and Daneshfar. 2015. Strategies of Transfering Hypothetical Mood in Translation of Hafiz's poems. International Journal of Enhanced Research in Educational Development. Vol 3, Issue 5.

Maasoum. 2013. Translation Shifts in the Persian Translation of a Tale of Two Cities by Charles Dickens. Academic Journal of Interdisciplinary Studies. Vol 2, No 1.

Masri D. 2005. Pintu Gerbang Gayo. Retrieved from http://lintasgayo.co/2015/04/14/onot-kemaradidong-pintu-gerbang-gayo Accessed on December, 12 2017

Miles, Huberman \& Saldana. 2014. Qualitative Data Analysis: A Method Source Book ( $3^{\text {rd }}$ Ed). USA: SAGE Publication Inc.

Miranti. 2017. Translation Shifts in Indonesian Version of Sheldon's Windmills of the Gods. Leksema Jurnal Bahasadan sastra. Vol 2, No 2.

Oxford Advanced Learners Dictionary. 1985. Oxford University Press.

Parkinson, G., \& Drislane, R. 2011. Qualitative research. In Online dictionary of the social sciences. Retrieved from http://bitbucket.icaap.org/dict.pl. Accessed on December, 02nd 2017.

Rahmawatie, Engliana, and Miranti. 2017. The Shifts of Functional words in the Translation of Toer's Bumi Manusia into English by Max Lane. Journal of language and Literature.

Rasyidie, Chikita, and Fridolini. 2013. Translation Shifts in the Novel "Mansfield Park" by Jane Austen Translated by Berliani Mantili Nugrahani. Jurnal Ilmu dan Budaya. Vol 1.

Rossa, Sinar, Bell, and Setia. 2015. Metafunctional Shifts in the Translation of Student and Propessional Translators. International Journal of Sciences: Basic and Applied Research.

Salemi and Lotfi. 2017. Structural Shifts in Humor Translation: A Case Study of Selected Books from Horrible History Volume. International Journal of Language Learning and Applied Linguistic World. Vol 16 (4).

Shih. 2012. A Corpus-Aided Study of Shifts in English-to-China Translation of Prepositions. International Journal of English Linguistic. Vol 2,No 6.

Widarti. 2015. An Analysis of Rank-Shift of Compound Complex Sentence Translation. Journal of Education and Practice. Vol.6, No 30. 